\title{
PRODUCTION OF PECTIN LYASE BY PENICILLIUM GRISEOROSEUM IN BIOREACTORS IN THE ABSENCE OF INDUCER
}

\author{
Roberta Hilsdorf Piccoli-Valle ${ }^{1 *}$; Flávia Maria Lopes Passos²; Frederico José Vieira Passos ${ }^{3}$; Daison Olzany Silva ${ }^{2}$ \\ ${ }^{1}$ Departamento de Ciência dos Alimentos, Universidade Federal de Lavras, Lavras, MG, Brasil. ${ }^{2}$ Departamento de \\ Microbiologia, BIOAGRO, Universidade Federal de Viçosa, Viçosa, MG, Brasil. ${ }^{3}$ Departamento de Tecnologia de Alimentos, \\ Universidade Federal de Viçosa, Viçosa, MG, Brasil.
}

Submitted: April 07, 2000; Returned to authors for corrections: September 14, 2000; Approved: May 25, 2001

\begin{abstract}
Penicillium griseoroseum was grown in bioreactors on mineral medium supplemented with yeast extract and sucrose. The influence of inoculum and carbon source concentrations, aeration and $\mathrm{pH}$ on pectin lyase (PL) production, as well as the capacity of $P$. griseoroseum to produce PL when grown on sugar cane syrup as carbon source were evaluated. Inoculum concentration did not influence PL production. Production was higher in nonaerated than in aerated medium. The best results were obtained using $60 \mathrm{mM}$ sucrose at $\mathrm{pH}$ 6.3-7.2. Production using cane syrup $25 \%$ (v/v), without yeast extract supplement, was equal to that obtained under the conditions cited above.
\end{abstract}

Key words: fermentation, pectin lyase, Penicillium griseoroseum, pectinases

\section{INTRODUCTION}

The utilization of microbial enzymes has found broad technological application in different industrial processes. Among the various enzymes commercialized, many are products of fermentation of filamentous fungi. Fungal pectinases are used in the food industry for the production of fruit juices, olive oil and wine to increase fruit juice and olive oil extraction yields and in the clarification of juices and wines. Pectic enzymes can also be used in the textile industry to degrade the pectin layer which covers cellulose fibers, thereby freeing the fibers for further processing (31).

Degumming of ramie is currently performed chemically, using hot alkaline soda. Deshpande and Guriecharanam (14) showed that natural fibers obtained by a combined chemical and enzymatic degumming process are of superior quality to those obtained by the chemical process alone. Another advantage of the combined process is the reduction of environmental pollution, since the volume of caustic soda used is reduced.

Among the pectinases, pectin lyase (PL) is of particular interest because it acts directly on pectin without the need for previous action by other enzymes of the pectinolytic complex (1). Degumming of ramie fibers with PL of Penicillium griseoroseum produces fibers with quality superior to those produced by a commercial enzyme complex because $P$. griseoroseum does not produce cellulolytic enzymes (10). Enzymes may be either constitutive or inducible. Inducible enzymes are, generally, produced at low level when the organism is grown in the absence of enzyme inducers. To pectic enzymes those inducers may be polygalacturonides, galacturonic acid, pectins or other pectic substances (18). Inducers, many times, are of high cost. So, means of alternative costs which promote the production of those enzymes are researched $(16,19)$.

Among the filamentous fungi, some of the genus Penicillium are good producers of PL (1). Penicillium griseoroseum produces PL when grown in a medium containing pectin (10), its natural inducer. However, its capacity of producing the enzyme when grown in sucrose without the presence of pectic substances was found (11). Studies show that the PL activity obtained is greater in this condition than when the cultivation mean is made up of pectin. Nevertheless, the addition of small contents of yeast extract, 0.6

\footnotetext{
* Corresponding author. Mailing address: Universidade Federal de Lavras, Departamento de Ciência dos Alimentos, Caixa Postal 37. 37200-000, Lavras,
} MG, Brasil. Phone: (+5535) 3829-1656. Fax: (+5535) 3829-1401. E-mail: rvalle@ufla.br. 
g.L.-1, proved necessary for PL production by P.griseoroseum when grown on sucrose (6). Induction of PL by some organic and inorganic compounds present in the yeast extract was investigated, being suggested that, probably cAMP present in the supplement is involved in the process (5). As in Brazil, sucrose is a low cost source of carbon and energy, its use in the cultivation of the fungus for obtaining PL is interesting.

The objective of the present study was to improve PL production by $P$. griseoroseum grown under different culture conditions in bench-scale bioreactors.

\section{MATERIALS AND METHODS}

\section{Microorganisms}

Penicillium griseoroseum CCT 6421 (Coleção de Cultura Tropical, Campinas, SP, Brazil) was isolated from seeds of forest tree species at the Department of Phytopathology of the Federal University of Viçosa, Minas Gerais, Brazil.

\section{Culture conditions}

The inoculum was obtained from $P$. griseoroseum cultures grown on oat agar for 9 days at $25^{\circ} \mathrm{C}$. The medium (MM) used for fungal culture was composed, except were mentioned, of (g.L $\left.\mathrm{L}^{-1}\right)$ : $\mathrm{K}_{2} \mathrm{HPO}_{4}, 2.48 ; \mathrm{KH}_{2} \mathrm{PO}_{4}, 8.0 ; \mathrm{MgSO}_{4} \cdot 7 \mathrm{H}_{2} \mathrm{O}, 1.0$ and $\left(\mathrm{NH}_{4}\right)_{2} \mathrm{SO}_{2}, 1.0$ at pH 6.3, supplemented with $19 \mathrm{mM}$ sucrose (Sigma $\left.{ }^{\circledR}\right)$ and $0.06 \%$ $(\mathrm{w} / \mathrm{v})$ yeast extract (Merckß). The fungus was grown under batch conditions, in Wheaton $250 \mathrm{~mL}$ ( $200 \mathrm{~mL}$ working volume) benchscale bioreactor (Milliville, NJ, USA), at $25^{\circ} \mathrm{C}$. Fifty $\mathrm{mM}$ Tris/sodium acetate/phosphate buffer (4) was used to evaluate the effect of $\mathrm{pH}$ on enzyme production. $\mathrm{MgSO}_{4} \cdot 7 \mathrm{H}_{2} \mathrm{O}$ and $\left(\mathrm{NH}_{4}\right)_{2} \mathrm{SO}_{4}$ were added to the buffer at the concentrations cited above. The medium was suplemented with $19 \mathrm{mM}$ sucrose (Sigma ${ }^{\circledR}$ ) and $0.06 \%(\mathrm{w} / \mathrm{v})$ yeast extract (Merck®).

\section{Growth determination}

Culture were harvested by filtering through a 400-mesh sieve (37- $\mu \mathrm{m}$ pore size) and growth was determined according to Calam (12).

\section{Enzyme assay}

PL activity was determined in the culture supernatant spectrophotometrically $\left(\mathrm{A}_{235}\right)$ according to Albersheim (2) as modified by Minussi et al. (26). Unit of PL activity (U) was defined as nanomoles of $\Delta^{4,5}$ galacturonide produced per $\mathrm{mL}$ of culture supernatant per minute of reaction, based on the molar extinction coefficient $(5,550)$ of the insaturated products (2).

\section{Residual sugar determination}

Free glucose concentration in the culture medium was determined by using glucose oxidase (GOD-PAK, commercial kit available from Merck). Residual sucrose was determined after its hydrolysis with $1 \%(\mathrm{w} / \mathrm{v})$ invertase (Sigma) at a 1:1 supernatant:enzyme volume ratio, in $50 \mathrm{mM}$ acetate buffer, at $\mathrm{pH}$ 4.5 and $50^{\circ} \mathrm{C}$ for 12 hours, followed by quantification of the glucose liberated by the glucose oxidase method.

\section{RESULTS AND DISCUSSION}

The capacity of microorganisms to produce extracellular enzymes is influenced by environmental conditions such as temperature, $\mathrm{pH}$, aeration, inoculum age and the presence of inducer or repressor substrates (15). Initially, the influence of the aeration of the cultivation medium of $P$. griseoroseum was investigated.

The observed activity of PL produced by $P$. griseoroseum grown under different modes of aeration is shown in Fig. 1. In the present study, PL activities of 27.2 units were obtained when air was bubbled through the medium via a sparger (treatment A, Fig. 2A) and 25.6 units when no air was added (treatment C, Fig. 2C). These activities were not significantly different at the $5 \%$ level (Duncan test). However, significantly lower PL activity (15.2 units) was obtained when air was injected into the bioreactor void volume (treatment B, Fig. 2B). Those PL activities obtained by the fungus cultivation in sucrose and yeast extract regardless of the influence of the aeration were about 13 times as great as those obtained by Brumano et al. (10) in growing the fungus in a medium containing pectin, the natural inducer of the enzyme. Those activities were also greater than those obtained by Santiago (29) by the cultivation of Penicillium expansum in the presence of pectin or by those obtained by the cultivation of other species of Penicillium (1,3). However, as compared with the activity obtained by the cultivation that a mutant species of Aspegillus niger (36), the ones obtained in this work were around

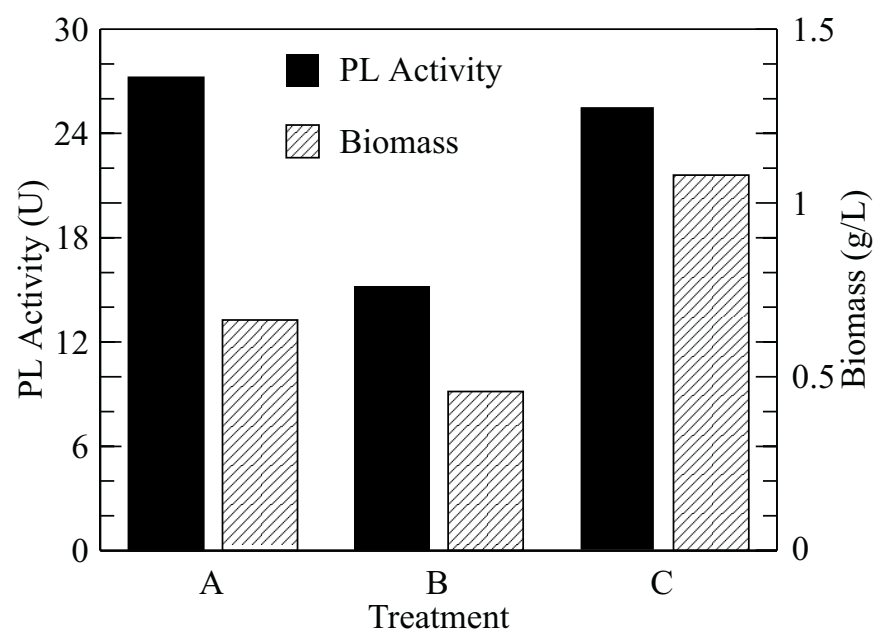

Figure 1. Influence of the type of aeration on PL production, after 48 hours of growth. Air injection via sparger (A), air injection to bioreactor void volume (B), no air injection (C). 

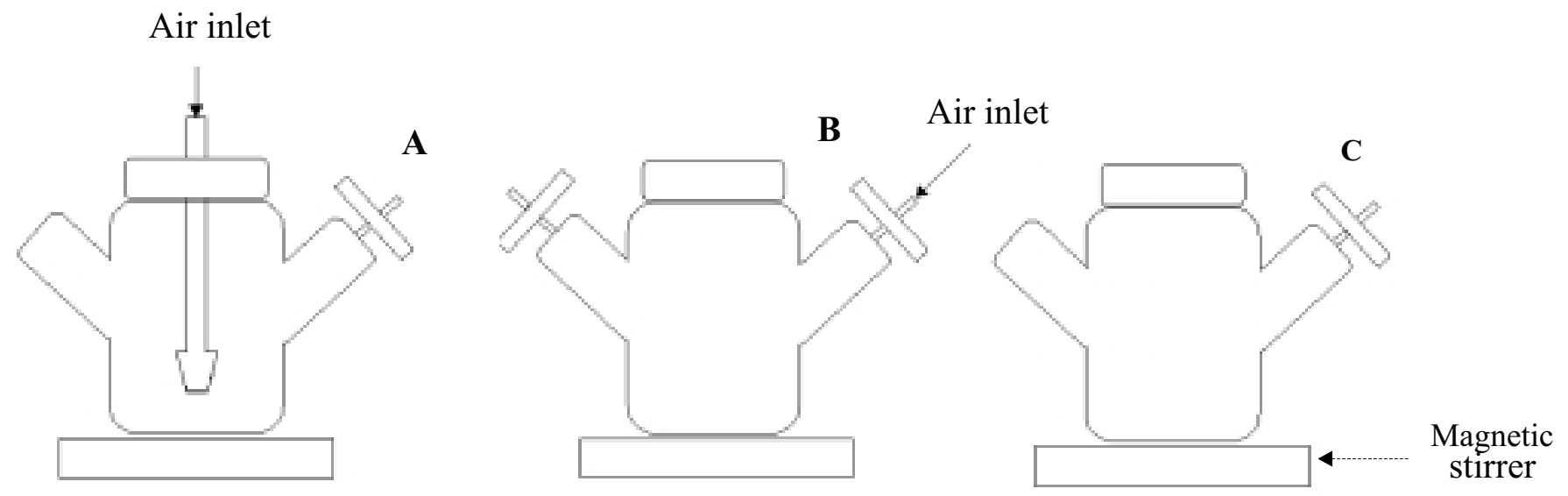

Figure 2. Schematic diagram of the bioreactors. Air injection via sparger (A), air injection to bioreactor void volume (B), no air injection (C). The arrows indicate air injection to bioreactor. The culture was homogenized by magnetic agitation.

1,000 greater smaller. But the comparison among the results obtained with those of the literature is difficult, since, in the several works on PL published, the enzyme activity was determined by different methodologies (7). The calculation of the conversion factors $Y_{P X X}$ for the three treatments show that in treatment $\mathrm{A}$, where the fungus grew in a immobilized form, the factor was greater, 41.1 , followed by 33.2 for treatment $B$ and 23.6 for $C$. That shows that in spite of the enzymatic activity in treatment B having been very low, there was a greater PL production per unit of mycelial mass than in treatment $\mathrm{C}$. Comparing the results with those obtained by Santiago (29) for $P$. expansum, PL activity per unit of mycelial mass of $P$. griseoroseum was about two times greater.

Friedrich et al. (17) showed that agitation and aeration affect PL, pectin esterase (PE), polygalacturonase (PG) and biomass production in a submerged culture of Aspergillus niger. Aspergillus awamori has also been shown to produce pectinases differentially when grown under various aeration regimes (15). In treatments $\mathrm{B}$ and $\mathrm{C}$, the fungus grew dispersed as pellets in the culture medium, whereas in treatment A the mycelia adhered to the surface of the air sparger. The growth of filamentous fungi is made by the determination of the weight of the dry mycelium when the type of cultivation utilized is submerse, provided the medium is not made up of solid particles as for example cereal meal $(13,23)$. In obtaining the filamentous growth, the samplings are more homogeneous if the cultivation medium is being stirred adequately and there will be no adherence on the internal surfaces of the reactor. However, when growth takes place in the form of pellets, there is a great difficulty in obtaining representative samples, one having then to increase the number of samples collected in each time and increase also the volume of each sample. But, in that experiment all the mycelia present in the bioreactor were collected at one time after 48 hours' cultivation, no sample being collected before that period.
Studies on A. awamori immobilized in a polyurethane sponge showed that this fungus produces 2 to 2.5 times more pectinase in the immobilized than in the free form (8). The process of immobilized fungal growth, as in the case of $P$. griseoroseum in the system using air sparging (treatment A), can lead to physiological alterations. One possible alteration can affect cell membrane permeability, promoting an increase in enzyme secretion in some cases (34). Hermsdörfer et al. (22) concluded that the biosynthesis of PG by A. niger is related to mycelial morphology. Specific activity of PG increases with the degree of mycelial compaction. The authors suggest that the synthesis of PG by A. niger is strictly related to limited oxygen and nutrient supplies.

Mycelial pellet formation is, in some cases, a prerequisite for high enzyme production. Aspergillus oryzae grown in the form of mycelial aggregates increases several fold the production of aamylase (8). It is known that the growth of filamentous microorganisms as dispersed elemental hypha or as pellets is affected by $\mathrm{pH}$ of the medium, inoculum concentration and presence of surfactants (28). However, Friedrich et al. (17) found no difference in PL and PG production in broth fermented by $A$. niger grown in a fermenter, using $10^{2}$ to $10^{8}$ spores $\mathrm{L}^{-1}$. In spite of the possible influence of inoculum concentration on morphology and enzyme production in filamentous fungi, $P$. griseoroseum was not shown to be affected by this parameter (date not shown). Fungal growth occurred in the aggregated form for all spore concentrations tested, without any significant differences in PL production. An inoculum concentration of $5 \times 10^{4}$ spores $\mathrm{mL}^{-1}$ was chosen for the remainder of this study.

The $\mathrm{pH}$ of the cultivation medium is an important factor in the production of pectinases for it influences the sort and content of those enzymes produced by fungi. High polygalacturonase and pectinesterase activities were verified in more acid cultivation $\mathrm{pH}$, 4.5 and 5.0, and of PL pH close to the neutral, 5.0 to 7.0 (33). The PL activity, verified after cultivation of $P$. griseoroseum in a medium 
with initial $\mathrm{pH}$ between 5.6 and 8.0 did not differ among them (5\% level) (Fig. 3). A pH value of 6.8 was chosen for the remainder of this work since PL shows optimum activity at this value (18).

The enzymes possess one or a $\mathrm{pH}$ range optimum of activity. The $\mathrm{pH}$ of the medium in which the enzyme is exposed affects the ionization state of its amino acids which dictate the primary and secondary structure of the enzyme, so controlling its activity (21). The influence of $\mathrm{pH}$ of the cultivation medium may be related directly with the stability of enzymes (33). Studies with PL of $P$. expansum showed that in spite of the optimum activity $\mathrm{pH}$ of $\mathrm{PL}$ to be 7.0, the enzyme kept stable between the $\mathrm{pH} 6.5$ to 8.0 (29), however the mechanism by which $\mathrm{pH}$ acts on the production of pectic enzymes is not known.

Significant PL production (65 units) was obtained by growing P. griseoroseum in medium containing 60 to $74 \mathrm{mM}$ sucrose (Fig. 3C). At the lower concentrations of carbon source utilized (11 and $19 \mathrm{mM}$ ), sucrose and glucose were depleted from the medium after 36 hours of growth (Fig. 3A and B). This justifies the low enzyme production observed under these growth conditions. It is known that the use of sucrose or glucose as substrate affects enzyme synthesis, with catabolic repression being observed when these substrates are at levels above 15 to $30 \mathrm{mM}$ (32). This type of relationship occurs not only in bacteria but also in fungi like $A$. niger, leading to interruption of $\mathrm{PG}$ and pectin esterase (24) and in P. expansum leading to reduction of PG synthesis (27). Schimidt et al. (30) also observed this phenomenon when growing $A$. niger in a fermenter using sucrose as carbon source. However, in the present study, PL production by $P$. griseoroseum does not appear to be influenced by concentrations of sucrose used or by the free glucose in the medium.

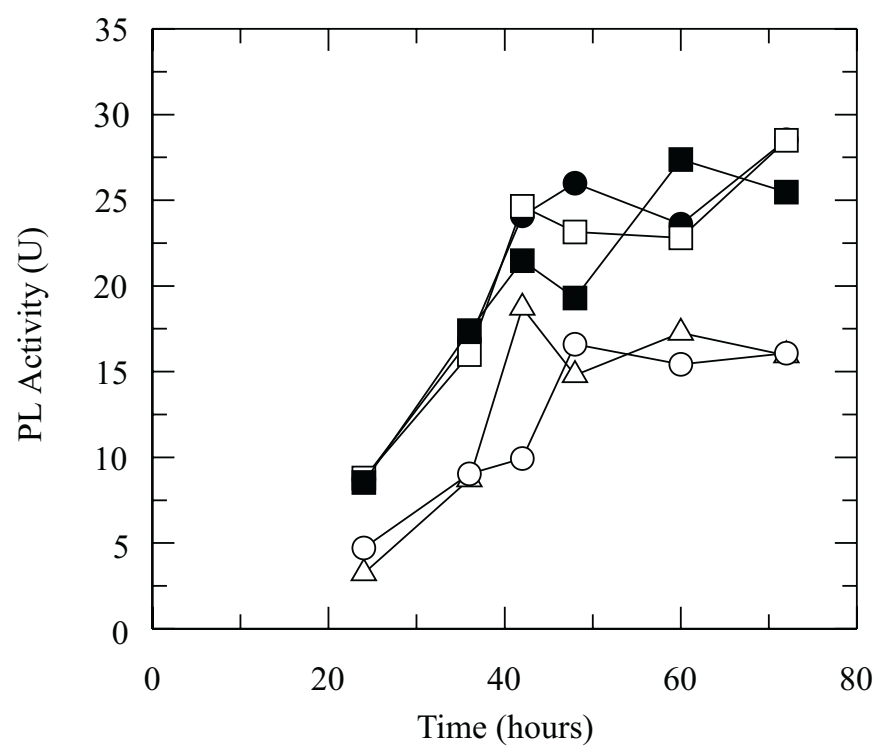

Figure 3. Influence of the culture medium $\mathrm{pH}$ on $\mathrm{PL}$ production

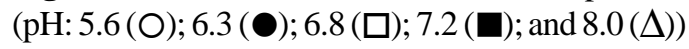

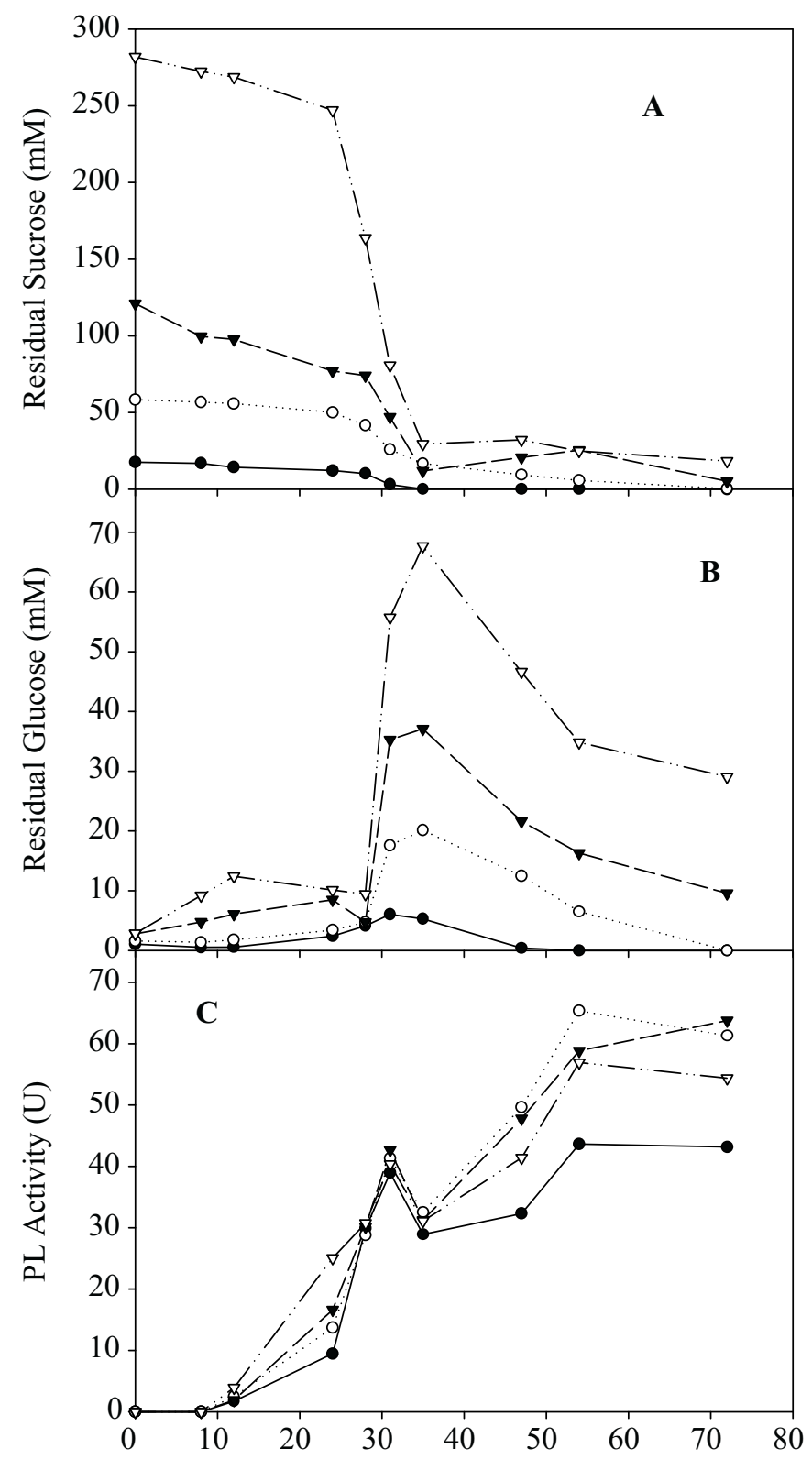

Figure 4. Sucrose consumption by $P$. griseoroseum over time (A), variation in free glucose in the growth medium (B), and PL production as a function of initial sucrose concentration (C), 19 $(\bullet), 60(O), 124(\boldsymbol{\nabla})$ and $285 \mathrm{mM}(\nabla)$.

Sugar cane syrup proved to be a good substrate for growth of P. griseoroseum in a bioreactor (Fig. 4A) using buffered medium. This result was expected since in experiments performed in Erlenmeyer flasks this fungus presented high PL production efficiency (25). The observed enzyme activity of 72 units was below that obtained previously (approximately 110 units) but was higher than that obtained in the present study when the fungus 


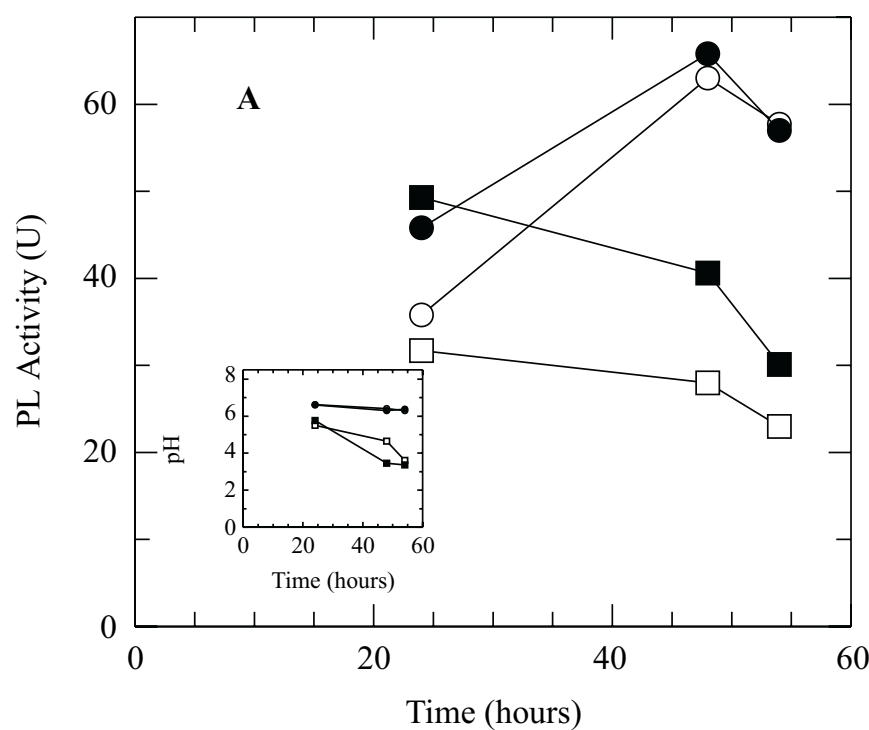

Figure 5. Penicillium griseoroseum grown on $25 \%$ sugar cane syrup: (A) PL production and (B) variation in $\mathrm{pH}$ of growth medium with different supplements: MM and yeast extract $(\mathbf{O}) ; \mathrm{MM}(\mathrm{O})$; yeast extract ( $\square$ ); no supplement $(\square)$.

was grown on sucrose. It is suggested that this difference in the quantity of PL in the medium is due to growth morphology, since in the mixing mode used the fungus grows as mycelial filaments and not as pellets. Filamentous growth can alter the fermentation broth rheology, thereby lowering oxygen and nutrient diffusion to the fungus, since lowering the viscosity of the medium decreases homogenization efficiency (9). Under these limiting conditions, enzyme production can be affected. Another possible explanation for the effect of fungal morphology on the quantity of enzyme is the dependence of enzyme production on growth in pellet form in $P$. griseoroseum. The relationship between fungal morphology and metabolite production was evidenced for production of PG (22) and gluconic acid (35) by A. niger and of xylanase by $A$. sydowii (20). The addition of yeast extract to the buffered medium did not affect PL production (Fig. 4). It is suggested that the low PL production observed in the unbuffered medium was responsible for the large $\mathrm{pH}$ drop (Fig. 4B) during the fermentation. Preliminary studies revealed that the addition of tea extract to the sucrose-containing medium also induces PL production. The possible inducers present in tea were methylxanthines. The sugar cane juice contains from 0.15 to $0.25 \%$ pectic substances, from 0.3 to $0.6 \%$ nitrogen containing compounds (aminoacids and xanthinic compounds) and $5.5 \%$ cellulose, among other compounds (26). It is possible that addition of yeast extract to the sugar cane juice was not necessary because of presence of pectic substances, which are natural pectinase inducers. Besides pectic substances, xanthines may also contribute, together with sucrose, to PL production.
The present study shows that pectin lyase production by $P$. griseoroseum in medium containing sucrose or sugar cane syrup as sole carbon and energy source is possible and that this fungus shows promise for future use in industrial PL production.

\section{ACKNOWLEDGMENTS}

The authors wish to thank the Brazilian agencies, FINEP and CAPES, for financial support.

\section{RESUMO \\ Produção de pectina liase por \\ Penicillium griseoroseum em biorreatores em ausência de indutor}

Penicillium griseoroseum foi cultivado em biorreatores em meio mineral suplementado com extrato de levedura e sacarose. As influências das concentrações do inóculo e da fonte de carbono, da aeração e do $\mathrm{pH}$ do meio de cultivo sobre a produção de pectina liase (PL), bem como a capacidade de $P$. griseoroseum em produzir PL quando cultivado em caldo de cana diluído foram avaliadas. A concentração do inóculo não influenciou significativamente a produção de PL. O cultivo do fungo em biorreatores não aerados favoreceu a produção da $\mathrm{PL}$ em detrimento aos biorreatores com injeção de ar. Maior produção de PL foi obtida com o cultivo de $P$. griseoroseum em meio com $\mathrm{pH}$ $6,3-7,2$, adicionado de $60 \mathrm{mM}$ de sacarose. Quando cultivado em caldo de cana diluído, $25 \%$ (v/v), sem suplementação com extrato de levedura, a atividade máxima de PL alcançada foi igual as das condições citadas acima.

Palavras-chave: fermentação, pectina liase, Penicillium griseoroseum, pectinases

\section{REFERENCES}

1. Alaña, A.; Alkorta, I.; Dominguez, J.B.; Llama, M.J.; Serra, J.L. Pectin lyase activity in Penicillium italicum strain. Appl. Environm. Microbiol., 56:3755-3759, 1990.

2. Albersheim, P. Pectin lyase from fungi. In: Neufeld, E.S.; Ginsgurg. V. (eds). Methods in Enzymology. vol. 8, Academic Press, New York, 1966, p.628-635.

3. Alkorta, I.; Garbisu, C.; Llama, M.J.; Serra, J.L. Industrial applications of pectic enzymes: a review. Process Biochem., 33:21-28, 1998.

4. Araújo, E.F.; Barros, E.G.; Caldas, R.A.; Silva, D.O. Beta-glucosidase activity of a thermophilic cellulolytic fungus, Humicola sp. Biotechnol. Lett, 5:781-784, 1993.

5. Baracat-Pereira, M.C.; Coelho, J.L.C.; Minussi, R.C.; Chaves-Alves, V.M.; Brandão, R.L.; Silva, D.O. Cyclic AMP low molecular weight effector (s) present in yeast extract are involved in pectin lyase production by Penicillium griseoroseum cultured in sucrose. Appl. Biochem. Biotechnol., 76: 129-141, 1999.

6. Baracat-Pereira, M.C.; Coelho, J.L.C.; Silva, D.O. Production of pectin lyase by Penicillium griseoroseum cultured on sucrose and yeast extract for degumming of natural fibres. Lett. Appl. Microbiol., 18:127-129, 1994. 
7. Bateman, D.F. Hydrolytic and trans-eliminative degradation of pectic substance by extracellular enzymes of Fusarium solani, f. phascoli. Phytopapatol., 56:238-244, 1966.

8. Bliyeva, R.K. Biosynthesis of enzymes by aggregated and immobilized mycelium of micromycetes. J. Microbiol. Biotechnol., 3:37-44, 1988.

9. Braun, S.; Vecht-Lifshitz, S.E. Mycelial morphology and metabolite production. Trends in Biotechnol., 9:63-68, 1991.

10. Brumano, M.H.N.; Coelho, J.L.C.; Araújo, E.F.; Silva, D.O. Pectin lyase activity of Penicillium griseoroseum related to degumming of ramie. Rev. Microbiol., 24:175-178, 1993.

11. Brumano, M.H.N.; Coelho, J.L.C.; Araújo, E.F.; Silva, D.O. Production of pectin lyase by Penicillium griseoroseum as a function of the inoculum and culture condiction. World J. Microbiol. Biotechnol., 9:225-228, 1993

12. Calam, C.T. The avaluation of mycelial growth. In: Mouranche, A.; Costes, C. Methods in Microbiology. London: Academic Press, 1969. V.1, p.567-591.

13. Cui, Y.Q.; Ouwehand, J.N.W.; van der Lans, R.G.J.M.; Giuseppin, M.L.F.; Luyben, K.C.A.M. Aspects of the use of complex media for submerged fermentation of Aspergillus awamori. Enzyme and Microbial Technol., 23:168-177, 1998.

14. Deshpande, K.S.; Guriecharanam, K. Degumming of ramie fibres: role of cell wall degrading enzymes of Aspergillus versicolor. J. Bot., 8:7981, 1985.

15. El-Refai, A.A.; Metwalli, S.M.; El-Sebaiy, L. A. Influence of pH, inoculum, aeration and growth period on production of pectinolytic enzymes by Penicillium awamori 16. Chem. Microbiol. Technol. Lebensm., 8:115-117, 1984.

16. Eveleigh, D.E.; Montenecourt, B.S. In: Perlman, D.O. (eds). Advances in Applied Microbiology. Academic Press, New York, 1979, p.57-75.

17. Friedrich, J.; Cimerma, A.; Steiner, W. Production of pectinolytic enzymes by Aspergillus niger: effect of inoculum size and potassium hexacyanoferrate II-trihydrate. Appl. Microbiol. Biotechnol., 33:377381, 1990.

18. Genari, R.; Minussi, R.C.; Silva, D.O. Partial physic-chemical characterization of pectin lyase produced by Penicillium griseoroseum cultured on sucrose-yeast extract or pectin. In: Xxv ${ }^{a}$ Reunião Anual da Sociedade Brasileira de Bioquímica e Biologia Molecular, Caxambú, MG, 1996. Programa e resumos. SBBq, p.73.

19. Ghildyal, N.P.; Ramakrishna, S.V.; Nirmala-Devi, P.; Losane, B.K.; Sthana, H.N. Large scale production of pectolytic enzyme by solid state fermentation. J. Fd. Sci. Technol., 18:248-251, 1981.

20. Ghosh, M.; Nanda, G. Immobilized Aspergillus sydowii produces xylanases. Biotechnol. Lett, 13:807-808, 1991.

21. Griffin, D.H. Fungal physiology. Wiley-Liss, New York, 1994, 458p.
22. Hermersdörfer, H.; Leuchtenberger, A.; Wardsach, Ch.; Ruttloff, H. Influence of culture conditions on mycelial struture and polygalacturonase synthesis of Aspergillus niger. J. Basic Microbiol., 27:309-315, 1987

23. Lejeune, R.; Baron, G.V. On the use of morphological measurements for the quantification of fungal growth. Biotechnol. Techniques, 9:327328, 1995.

24. Maldonado, M.C.; Saad, A.M.S.; Callieri, D. Catabolic repression of the synthesis of inducible poligalacturonase and pectinesterase by Aspergillus niger sp. Curr. Microbiol., 18:303-306, 1989.

25. Minussi, R.C.; Soares-Ramos, J.R.L.; Coelho, J.L.C.; Silva, D.O. Sugarcane juice induces pectin lyase and polygalacturonase in Penicillium griseoroseum. Rev. Microbiol., 29:246-250, 1998.

26. Minussi, R.C.; Baracat-Pereira, M.C.; Coelho, J.L.C.; Silva, D.O. Methylxanthinas as inducers of pectin lyase in Penicillium griseoroseum cultured on sucrose. Lett. App. Microbiol., 24: 369-372, 1997.

27. Piccoli-Valle, R.H.; Baracat-Pereira, M.C.; Silva, D.O. Catabolite repression of inductive polygalacturonase synthesis in Penicillium expansum. J. Basic Microbiol., 35:189-193, 1995.

28. Prosser, J.I.; Tough, A.J. Growth mechanisms and growth-kinetics of filamentous microorganisms. Crit. Rev. Biotechnol., 10:253-274, 1991.

29. Santiago, M.F. Produção e propriedades de pectina liase de um isolado Penicillium expansum. M.S., 1993. Dissertation, Universidade Federal de Viçosa, Viçosa, Brazil.

30. Schmidt, O.; Angermann, H.; Frommhold-Treu, I.; Hoppe, K. Experimental and theorical investigation of submerged fermentation and synthesis of pectinolytic enzymes by Aspergillus niger. Appl. Microbiol. Biotechnol., 43:424-430, 1995.

31. Sharma, H.S.S. Screening of polysaccharide-degrading enzyme for retting flax stem. Inter. Biodeterioration., 23:181-186, 1987.

32. Shinmyo, A.; Davis, L.; Nomoto, T.; Tahara, T.; Enatsu T. Catabolite repression of hydrolases in Aspergillus niger. Eur. J. Appl. Microbiol. Biotechnol., 50:59-68, 1978.

33. Ueda, S.; Fujio, Y.; Lim, J.Y. Production and some properties of pectic enzymes from Aspergillus orizae A-3. J. Appl. Biochem., 4:52405242, 1982.

34. Vassilev, N.; Vassileva, M. Production of organic acids by immobilized filamentous fungi. Mycol. Res., 96:563-570, 1992.

35. Vassilev, N.B.; Vassileva, M.C.; Spassova, D.I. Production of gluconic acid by Aspergillus niger immobilized on polyurethane foam. Appl. Microbiol. Biotechnol., 39:285-288, 1993.

36. Zetelaki-Hortváth, K. Possibilities control of pectolytic enzyme formation by Aspergillus niger in continuous culture. Acta. Alimentaria, 12:11-19, 1983. 